\title{
Hoe dit boek te gebruiken
}

Elk hoofdstuk begint met een uitleg van wat er in het hoofdstuk wordt behandeld. Dit wordt steeds geïllustreerd aan de hand van voorbeelden van mensen met lichamelijke klachten. Daarna volgen oefeningen die we huiswerk hebben genoemd. Ook geven we voorbeelden van hoe het huiswerk gemaakt kan worden. Ieder mens is uniek, en er zijn heel veel verschillende lichamelijke klachten waar mensen last van kunnen hebben. Dat is de reden dat we veel verschillende voorbeelden geven. Sommige voorbeelden zullen herkenbaar zijn en andere weer niet, omdat $u$ andere klachten hebt of met andere gevolgen van de klachten in uw maag zit.

Voordat u naar de therapeut gaat, leest $u$ het hoofdstuk dat bij die sessie hoort. Ook doet $\mathrm{u}$ de bijbehorende opdrachten. We hebben geprobeerd de opdrachten zo duidelijk en overzichtelijk mogelijk te maken. Toch kan het zijn dat u er niet uitkomt of dat er nog iets onduidelijk is. Zo is bijvoorbeeld het bedenken van oplossingen voor de klachten die $\mathrm{u}$ al lange tijd hebt, waarschijnlijk niet heel eenvoudig, want anders had $\mathrm{u}$ al lang zelf kunnen bedenken wat $\mathrm{u}$ te doen staat en zou therapie niet nodig zijn. Maak daarom gerust gebruik van hulp bij de opdrachten. Vraag ook hulp aan de therapeut, die is ervoor en hij is erin gespecialiseerd u te helpen bij dit soort klachten. Het is niet erg als u er met een van de opdrachten niet goed uitkomt. Bespreek het in de sessie en maak de opdracht af met hulp van de therapeut. 